\title{
Application of Occlusal Indices in Orthodontic Practice
}

\author{
Jelena Djordjević, Ivana Šćepan, Branislav Glišić \\ Department of Orthodontics, School of Dentistry, University of Belgrade, Belgrade, Serbia
}

\begin{abstract}
SUMMARY
Introduction Occlusal indices were designed to improve diagnostic criteria and to enable an objective assessment of malocclusion severity. The aim of this study was to present the most frequently used occlusal indices in orthodontic practice and to determine their reliability when applied to dental models.

Material and Methods Three occlusal indices were selected for analysis: the Index of Orthodontic Treatment Need (IOTN), the Peer Assessment Rating Index (PAR) and the Index of Complexity, Outcome and Need (ICON). Twenty dental models of patients referred to Department of Orthodontics, School of Dentistry, Belgrade, with malocclusions of different type and severity were used in this study. All dental models were measured by three afore mentioned indices twice, two months apart, in order to determine intraexaminer reliability.

Results The results showed that three indices had good reliability. Weighted Kappa was calculated for IOTN ( 0.72 and 0.79 for the aesthetic and the dental health component, respectively) and root mean square error was calculated for PAR and ICON (2.1 and 4.5, respectively). There was no statistically significant difference in scores between two measurements of these two indices $(p<0.01)$.

Conclusion Application of occlusal indices enables orthodontists to determine priorities in patient care, planning of orthodontic service, monitoring and promotion of standards. Occlusal indices are reliable diagnostic criteria.
\end{abstract}

Keywords: dental models; malocclusion; occlusal indices; orthodontics

\section{INTRODUCTION}

It has been stated for years that orthodontic treatment improves dental health, oral functions, facial aesthetics and quality of life. Conversely, more attention has been given recently to potential risks of orthodontic treatment: root resorption, enamel decalcification, gingival inflammation, loss of periodontal support, pulpal inflammation, allergic reaction, trauma, iatrogenic damage, unsuccessful treatment and relapse [1]. The benefits and risks of orthodontic treatment should be considered seriously prior to treatment. Precise diagnosis is needed for that purpose. In the last four decades numerous occlusal indices were suggested in order to improve diagnostic criteria [2].

Occlusal indices can be classified into five categories: diagnostic indices, epidemiological indices, indices of orthodontic treatment need, indices of orthodontic treatment outcome and indices of orthodontic treatment complexity [3]. The methods which are used to describe, assess and clasify malocclusion can be divided into qualitative and quantitative. They differ not only by morphological or functional criteria, but also by means of assessment: on dental models, clinically or both [4]. Literature review reveals that three occlusal indices are the most frequently used in orthodontic practice.

The Index of Orthodontic Treatment Need (IOTN), originally named the Index of Orthodontic Treatment Priority, was suggested by Evans and Shaw [5, 6] in 1987. IOTN is used for epidemiological purpose and to determine individual need for orthodontic treatment [7]. The Peer Assessment Rating Index (PAR) belongs to group of indices of orthodontic treatment outcome. British Standards Working Party is responsible for development of PAR in 1992 [8]. The Index of Complexity, Outcome and Need (ICON) was designed, as suggested by its name, to unite assessments of treatment need, complexity and outcome. Daniels and Richmond [9] developed this index based on results of international study in 2000 .

The aim of this study was to present the most frequently used occlusal indices and to determine their reliability when applied to dental models.

\section{MATERIAL AND METHODS}

Twenty dental models of patients referred to Department of Orthodontics, School of Dentistry in Belgrade, were used in this study. Malocclusions of different type and severity in permanent dentition were chosen. Dental models of patients suffering from craniofacial deformities and clefts were excluded from the sample. All dental models were numbered and three occlusal indices IOTN, PAR and ICON scored twice, two months apart. In order to avoid scoring bias, the models were randomized. A specially designed scoring sheet was used to collect the data. One examiner performed dental models assessment.

Statistical analysis was performed in Statistical Package for Social Sciences (SPSS), version 11.5 (Chicago, Illinois). The weighted Kappa coefficient with 95\% confidence interval was used to determine reliability of the Aesthetic and the Dental Health Components of IOTN, considering categorical data for this index. The weighted Kappa coefficient is a modification of unweighted Kappa. Each deviation from exact agreement of two measurements has its own weights [10]. Possible values for weighted Kappa coefficient lie between 0 (agreement no better than chance) 
Table 1. Dental Health Component of the Index of Orthodontic Treatment Need (IOTN) [10]

Tabela 1. Zdravstveni deo IOTN [10]

\begin{tabular}{|c|c|c|}
\hline \multirow{6}{*}{$\begin{array}{l}\text { Grade } 5 \\
\text { Ocena } 5\end{array}$} & $\mathrm{a}$ & $\begin{array}{l}\text { Increased overjet }>9 \mathrm{~mm} \\
\text { Incizalni stepenik veći od } 9 \mathrm{~mm}\end{array}$ \\
\hline & $\mathrm{h}$ & $\begin{array}{l}\text { Extensive hypodontia with restorative implications (more than one tooth missing in any quadrant) requiring pre-restorative } \\
\text { orthodontics } \\
\text { Opsežna hipodoncija (dva ili više zuba nedostaju po kvadrantu) koja zahteva prerestaurativno ortodontsko zbrinjavanje }\end{array}$ \\
\hline & $\mathrm{i}$ & $\begin{array}{l}\text { Impeded eruption of teeth (with the exception of third molars) due to crowding, displacement, the presence of supernumerary } \\
\text { teeth, retained deciduous teeth and any pathological cause } \\
\text { Onemogućeno nicanje zuba (s izuzetkom umnjaka) usled teskobe, ektopičnog položaja, prekobrojnih zuba, mlečnog zuba i bilo ko- } \\
\text { jeg patološkog uzroka }\end{array}$ \\
\hline & $\mathrm{m}$ & $\begin{array}{l}\text { Reverse overjet }>3.5 \mathrm{~mm} \text { with reported masticatory and speech difficulties } \\
\text { Negativni incizalni stepenik veći od } 3,5 \mathrm{~mm} \text { s problemima pri žvakanju i govoru }\end{array}$ \\
\hline & $\mathrm{p}$ & $\begin{array}{l}\text { Defects of cleft lip and palate } \\
\text { Defekti rascepa usne i nepca }\end{array}$ \\
\hline & $\mathrm{s}$ & $\begin{array}{l}\text { Submereged deciduous teeth } \\
\text { Mlečni zubi ispod nivoa susednih stalnih zuba (u infraokluziji) }\end{array}$ \\
\hline \multirow{11}{*}{$\begin{array}{l}\text { Grade } 4 \\
\text { Ocena } 4\end{array}$} & $a$ & $\begin{array}{l}\text { Increased overjet } 6 \leq 9 \mathrm{~mm} \\
\text { Incizalni stepenik veći od } 6 \mathrm{~mm} \text {, a manji od } 9 \mathrm{~mm}\end{array}$ \\
\hline & $b$ & $\begin{array}{l}\text { Reverse overjet }>3.5 \mathrm{~mm} \text { with no masticatory or speech difficulties } \\
\text { Negativni incizalni stepenik veći od } 3,5 \mathrm{~mm} \text {, bez problema pri žvakanju i govoru }\end{array}$ \\
\hline & C & $\begin{array}{l}\text { Anterior or posterior crossbite with }>2 \mathrm{~mm} \text { discrepancy between retruded contact position and intercuspal position } \\
\text { Prednji ili bočni ukršten zagrižaj, s razlikom između retrudovanog kontaktnog položaja i položaja maksimalne interkuspidacije ve- } \\
\text { ćom od } 2 \mathrm{~mm}\end{array}$ \\
\hline & $d$ & $\begin{array}{l}\text { Severe displacements of teeth }>4 \mathrm{~mm} \\
\text { Nepravilan položaj zuba veći od } 4 \mathrm{~mm}\end{array}$ \\
\hline & $\mathrm{e}$ & $\begin{array}{l}\text { Extreme lateral or anterior open bites }>4 \mathrm{~mm} \\
\text { Ekstremni prednji ili bočni otvoren zagrižaj veći od } 4 \mathrm{~mm}\end{array}$ \\
\hline & $f$ & $\begin{array}{l}\text { Increased and complete overbite with labial or palatal trauma } \\
\text { Dubok zagrižaj a povredom desni s labijalne ili palatinalne strane (gornji zubi potpuno preklapaju donje zube) }\end{array}$ \\
\hline & $\mathrm{g}$ & $\begin{array}{l}\text { Less extensive hypodontia (one tooth missing per quadrant) requiring pre-restorative orthodontics or orthodontic space closure } \\
\text { Hipodoncija manjeg obima (nedostaje jedan zub po kvadrantu) koja zahteva prerestaurativno ortodontsko zbrinjavanje ili zatvara- } \\
\text { nje prostora }\end{array}$ \\
\hline & I & $\begin{array}{l}\text { Posterior lingual crossbite with no functional oclusal contact in one or both buccal segments } \\
\text { Potpun bočni ukršten zagrižaj bez funkcionalnih okluzivnih kontakata u jednom bočnom segmentu ili oba }\end{array}$ \\
\hline & $\mathrm{m}$ & $\begin{array}{l}\text { Reverse overjet } 1 \leq 3.5 \mathrm{~mm} \text { with recorded masticatory and speech difficulties } \\
\text { Negativni incizalni stepenik veći od } 1 \mathrm{~mm} \text {, a manji od } 3,5 \mathrm{~mm} \text {, s problemima pri žvakanju i govoru }\end{array}$ \\
\hline & $\mathrm{t}$ & $\begin{array}{l}\text { Partially erupted teeth, tipped and impacted against adjacent teeth } \\
\text { Delimično iznikli, inklinirani zubi }\end{array}$ \\
\hline & $x$ & $\begin{array}{l}\text { Supplemental teeth } \\
\text { Prekobrojni zubi }\end{array}$ \\
\hline \multirow{6}{*}{$\begin{array}{l}\text { Grade } 3 \\
\text { Ocena } 3\end{array}$} & $a$ & $\begin{array}{l}\text { Increased overjet } 3.5 \leq 6 \mathrm{~mm} \text { with incompetent lips } \\
\text { Incizalni stepenik veći od } 3,5 \mathrm{~mm} \text {, a manji od } 6 \mathrm{~mm} \text {, s inkompetentnim usnama }\end{array}$ \\
\hline & $b$ & $\begin{array}{l}\text { Reverse overjet } 1 \leq 3.5 \mathrm{~mm} \\
\text { Negativni incizalni stepenik veći od } 1 \mathrm{~mm} \text {, a manji od } 3,5 \mathrm{~mm}\end{array}$ \\
\hline & C & $\begin{array}{l}\text { Anterior or posterior crossbite with } 1 \leq 2 \mathrm{~mm} \text { discrepancy between retruded contact position and intercuspal position } \\
\text { Prednji ili bočni ukršteni zagrižaj, razlika između retrudovanog kontaktnog položaja i položaja maksimalne interkuspidacije } 1-2 \mathrm{~mm}\end{array}$ \\
\hline & $d$ & $\begin{array}{l}\text { Displacement of teeth } 2 \leq 4 \mathrm{~mm} \\
\text { Nepravilan položaj zuba više od } 2 \mathrm{~mm} \text {, a manje od } 4 \mathrm{~mm}\end{array}$ \\
\hline & $\mathrm{e}$ & $\begin{array}{l}\text { Lateral or anterior open bite } 2 \leq 4 \mathrm{~mm} \\
\text { Prednji ili bočni otvoreni zagrižaj veći od } 2 \mathrm{~mm} \text {, a manji od } 4 \mathrm{~mm}\end{array}$ \\
\hline & $f$ & $\begin{array}{l}\text { Increased and complete overbite without labial or palatal trauma } \\
\text { Dubok zagrižaj bez povrede desni na labijalnoj ili palatinalnoj strani sekutića }\end{array}$ \\
\hline \multirow{6}{*}{$\begin{array}{l}\text { Grade } 2 \\
\text { Ocena } 2\end{array}$} & $a$ & $\begin{array}{l}\text { Increased overjet } 3.5 \leq 6 \mathrm{~mm} \text { with competent lips } \\
\text { Incizalni stepenik veći od } 3,5 \mathrm{~mm} \text {, a manji od } 6 \mathrm{~mm} \text {, s kompetentnim usnama }\end{array}$ \\
\hline & $b$ & $\begin{array}{l}\text { Reverse overjet } 1 \leq 0 \mathrm{~mm} \\
\text { Negativni incizalni stepenik manji ili jednak } 1 \mathrm{~mm}\end{array}$ \\
\hline & C & $\begin{array}{l}\text { Anterior or posterior crossbite with } \leq 1 \mathrm{~mm} \text { discrepancy between retruded contact position and intercuspal position } \\
\text { Prednji ili bočni ukršten zagrižaj, razlika između retrudovanog kontaktnog položaja (RKP) i položaja maksimalne interkuspidacije } \\
(\mathrm{IKP}) \text { manja ili jednaka } 1 \mathrm{~mm}\end{array}$ \\
\hline & $d$ & $\begin{array}{l}\text { Displacement of teeth } 1 \leq 2 \mathrm{~mm} \\
\text { Nepravilan položaj zuba, više od } 1 \mathrm{~mm} \text {, a manje od } 2 \mathrm{~mm}\end{array}$ \\
\hline & $\mathrm{e}$ & $\begin{array}{l}\text { Anterior or posterior open bite } 1 \leq 2 \mathrm{~mm} \\
\text { Prednji ili bočni otvoren zagrižaj veći od } 1 \mathrm{~mm} \text {, a manji od } 2 \mathrm{~mm}\end{array}$ \\
\hline & $f$ & $\begin{array}{l}\text { Increased and complete overbite without labial or palatal trauma } \\
\text { Vertikalni preklop sekutića veći od 3,5 mm, bez kontakta zuba sa desnima }\end{array}$ \\
\hline $\begin{array}{l}\text { Grade } 1 \\
\text { Ocena } 1\end{array}$ & & $\begin{array}{l}\text { Extremely minor malocclusions including displacements }<1 \mathrm{~mm} \\
\text { Mala odstupanja od normalne okluzije, promene položaja zuba manje od } 1 \mathrm{~mm}\end{array}$ \\
\hline
\end{tabular}

Qualifiers used to identify deviant occlusal traits: $a$ - overjet; $b$ - reverse overjet with no masticatory or speech problems; $c$ - crossbite; $d$ - displacement of contact points; e - open bite; $f$ - deep bite; $h$ - hypodontia; $i$ - impeded eruption; I - posterior lingual crossbite; $m$ - reverse overjet with masticatory or speech problems; $p$ - defects of cleft lip and palate; $s$ - submerged deciduous teeth; $t$ - partially erupted teeth, tipped and impacted against adjacent teeth; $x$ - presence of supernumerary teeth

Oznake okluzivnih anomalija: a - incizalni stepenik; b - negativni incizalni stepenik bez problema pri žvakanju i govoru; $c$ - ukršten zagrižaj; $d$ - nepravilan položaj zuba; e - otvoren zagrižaj; $f$ - dubok zagrižaj; $h$ - hipodoncija; i - onemogućeno nicanje zuba; I - bočni ukršten zagrižaj; $m$ - negativni incizalni stepenik sa problemima pri žvakanju i govoru; $p$ - defekti rascepa usne i nepca; s - mlečni zubi u infraokluziji; $t$ - delimično iznikli, inklinirani i impaktirani zubi; $x$ - prisustvo prekobrojnih zuba 

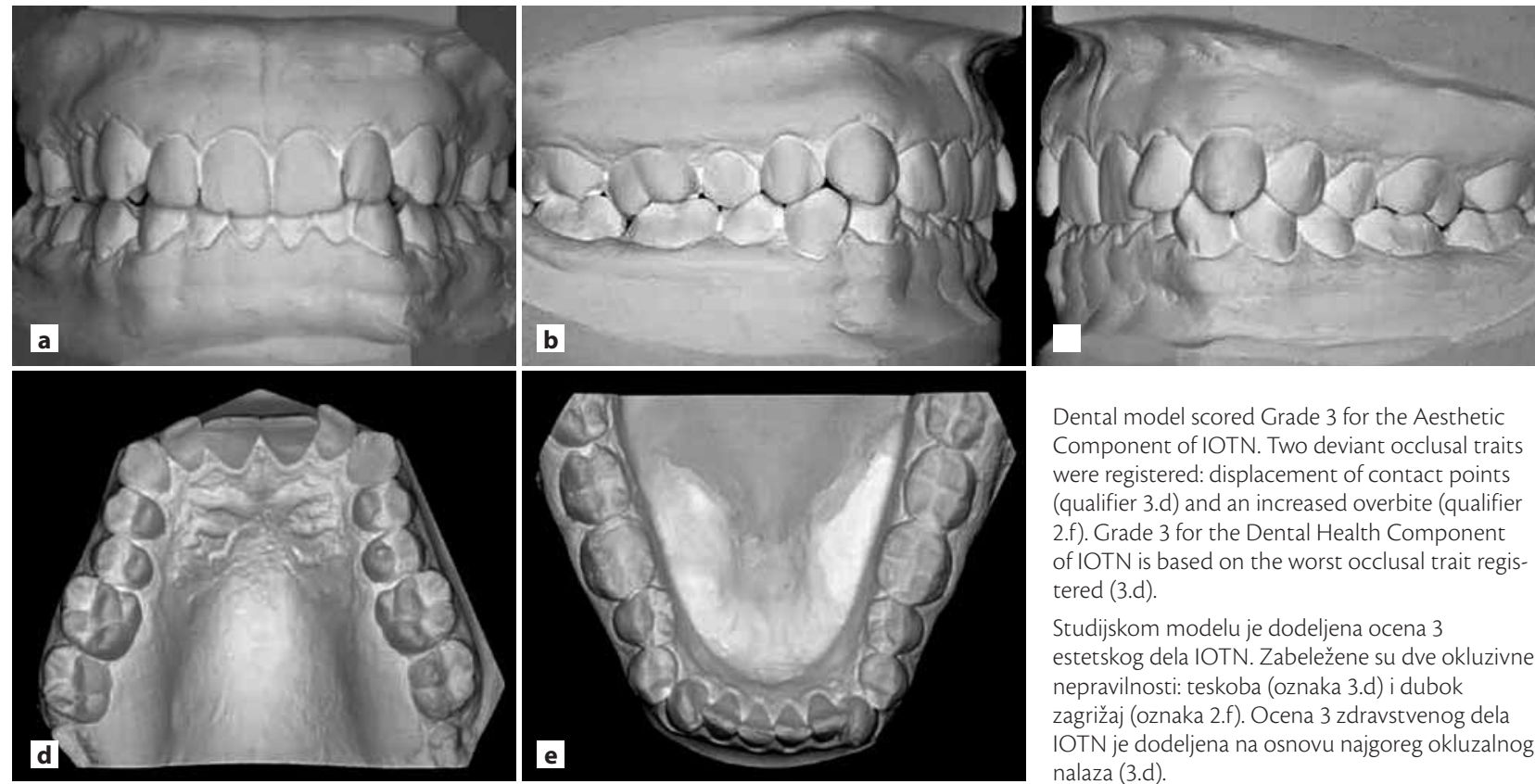

Dental model scored Grade 3 for the Aesthetic Component of IOTN. Two deviant occlusal traits were registered: displacement of contact points (qualifier 3.d) and an increased overbite (qualifier 2.f). Grade 3 for the Dental Health Component of IOTN is based on the worst occlusal trait registered (3.d).

Studijskom modelu je dodeljena ocena 3 estetskog dela IOTN. Zabeležene su dve okluzivne nepravilnosti: teskoba (oznaka 3.d) i dubok zagrižaj (oznaka 2.f). Ocena 3 zdravstvenog dela IOTN je dodeljena na osnovu najgoreg okluzalnog nalaza (3.d)

Figure 1a-e. Dental model assessed by the Index of Orthodontic Treatment Need (IOTN) Slika 1a-e. Studijski model ocenjen sa IOTN
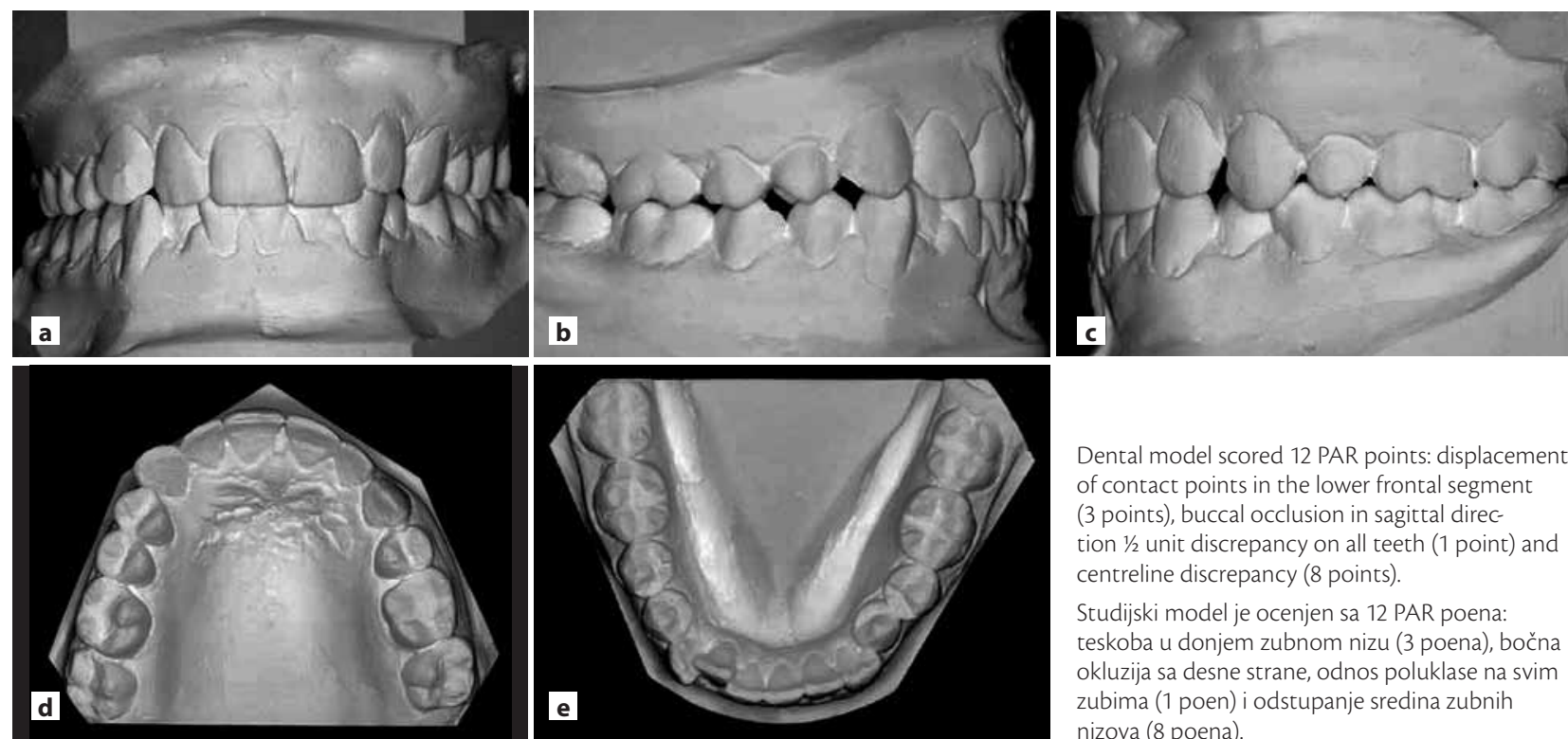

Dental model scored 12 PAR points: displacement of contact points in the lower frontal segment (3 points), buccal occlusion in sagittal direction $1 / 2$ unit discrepancy on all teeth (1 point) and centreline discrepancy (8 points).

Studijski model je ocenjen sa 12 PAR poena: teskoba u donjem zubnom nizu (3 poena), bočna okluzija sa desne strane, odnos poluklase na svim zubima (1 poen) i odstupanje sredina zubnih nizova (8 poena).

Figure 2a-e. Dental model assessed by the Peer Assessment Rating (PAR) Index Slika 2a-e. Studijski model ocenjen PAR indeksom

and 1 (perfect agreement). Reliability of PAR and ICON, whose data are continuous, is calculated by the Root Mean Square Error (RMS). The RMS error summarizes both random error (measurement error) and bias if present. $T$ test was performed to test for any statistically significant difference between the two measurements of PAR and ICON, with level of significance 0.01 .

\section{The Index of Orthodontic Treatment Need (IOTN)}

IOTN comprises two components: Aesthetic and Dental Health $[5,6]$. The Aesthetic Component consists of 10 frontal photographs of permanent dentition. The Dental Health Component categorizes deviant occlusal traits into five categories based on their detrimental effects on oral health. Missing teeth, overjet, crossbite, overbite and displacement of contact points are considered the most important. The grade is based on the most severe occlusal trait recorded (Table 1, Figure 1).

\section{The Peer Assessment Rating Index (PAR)}

PAR records crowding, spacing and impacted teeth in upper and lower anterior segments of dental arches, buccal occlusion in sagittal, vertical and transverse dimensions, overjet, anterior crossbite, overbite/openbite and centreline discrepancies [8]. Scores are assigned to deviant occlusal traits, multiplied by different coefficients and summed to 
produce an overall total. (Table 2, Figure 2). The difference between pre and post intervention scores represents the outcome of a treatment. An orthodontic treatment can be considered successful if percentage improvement at the end of treatment is greater than $70 \%$.

\section{The Index of Complexity, Outcome and Need (ICON)}

ICON records dental aesthetics, upper arch crowding/spacing, buccal occlusion in sagittal dimension, crossbite and

Table 2. Scoring system of the Peer Assessment Rating (PAR) Index [10]

Tabela 2. Sistem bodovanja PAR indeksa [10]

\begin{tabular}{|c|c|c|c|c|}
\hline \multicolumn{2}{|l|}{$\begin{array}{l}\text { Occlusal characteristics } \\
\text { Obeležja okluzije }\end{array}$} & $\begin{array}{l}\text { Severity } \\
\text { Mera izraženosti }\end{array}$ & $\begin{array}{l}\text { Scores } \\
\text { Bodovi }\end{array}$ & $\begin{array}{l}\text { Weighting } \\
\text { Koeficijenti }\end{array}$ \\
\hline \multirow{6}{*}{\multicolumn{2}{|c|}{$\begin{array}{l}\text { Contact points displacement for upper and lower } \\
\text { anterior segments } \\
\text { Rastojanje između kontaktnih tačaka agonista } \\
\text { prednjih segmenata zubnih nizova }\end{array}$}} & 0-1 mm & 0 & \multirow{6}{*}{ 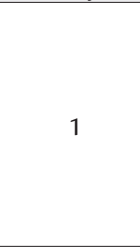 } \\
\hline & & $1.1-2 \mathrm{~mm}$ & 1 & \\
\hline & & $2.1-4 \mathrm{~mm}$ & 2 & \\
\hline & & $4.1-8 \mathrm{~mm}$ & 3 & \\
\hline & & $>8 \mathrm{~mm}$ & 4 & \\
\hline & & $\begin{array}{l}\text { Impacted teeth } \\
\text { Impaktirani zubi }\end{array}$ & 5 & \\
\hline \multirow{10}{*}{$\begin{array}{l}\text { Buccal occlusion } \\
\text { Bočna okluzija }\end{array}$} & \multirow{3}{*}{$\begin{array}{l}\text { Sagittal } \\
\text { Sagitalno }\end{array}$} & $\begin{array}{l}\text { Good interdigitation } \\
\text { Dobra interkuspidacija }\end{array}$ & 0 & \multirow{3}{*}{1} \\
\hline & & $\begin{array}{l}\text { Less than } 1 / 2 \text { unit from full interdigitation } \\
\text { Manje od } 1 / 2 \text { klase do pune interkuspidacije }\end{array}$ & 1 & \\
\hline & & $\begin{array}{l}1 / 2 \text { unit discrepancy on any tooth } \\
1 / 2 \text { klase na bilo kom zubu }\end{array}$ & 2 & \\
\hline & \multirow{2}{*}{$\begin{array}{l}\text { Vertical } \\
\text { Vertikalno }\end{array}$} & $\begin{array}{l}\text { No open bite } \\
\text { Nema otvorenog zagrižaja } \\
\end{array}$ & 0 & \multirow{2}{*}{1} \\
\hline & & $\begin{array}{l}\text { Lateral open bite on at least two teeth }>2 \mathrm{~mm} \\
\text { Otvoren zagrižaj na bar } 2 \text { zuba veći od } 2 \mathrm{~mm}\end{array}$ & 1 & \\
\hline & \multirow{5}{*}{$\begin{array}{l}\text { Transverse } \\
\text { Transverzalno }\end{array}$} & $\begin{array}{l}\text { No crossbite } \\
\text { Nema ukrštenog zagrižaja }\end{array}$ & 0 & \multirow{5}{*}{1} \\
\hline & & $\begin{array}{l}\text { Crossbite tendency } \\
\text { Tendencija ka ukrštenom zagrižaju }\end{array}$ & 1 & \\
\hline & & $\begin{array}{l}\text { Single tooth in crossbite } \\
\text { Jedan zub u ukrštenom zagrižaju }\end{array}$ & 2 & \\
\hline & & $\begin{array}{l}\text { More than one tooth in crossbite } \\
\text { Više zuba u ukrštenom zagrižaju }\end{array}$ & 3 & \\
\hline & & $\begin{array}{l}\text { More than one tooth in scissors bite } \\
\text { Više zuba u bukalnom promašaju }\end{array}$ & 4 & \\
\hline \multirow{5}{*}{\multicolumn{2}{|c|}{$\begin{array}{l}\text { Overjet } \\
\text { Incizalni stepenik }\end{array}$}} & $0-3 \mathrm{~mm}$ & 0 & \multirow{5}{*}{6} \\
\hline & & $3.1-5 \mathrm{~mm}$ & 1 & \\
\hline & & $5.1-7 \mathrm{~mm}$ & 2 & \\
\hline & & $7.1-9 \mathrm{~mm}$ & 3 & \\
\hline & & $>9 \mathrm{~mm}$ & 4 & \\
\hline \multirow{5}{*}{\multicolumn{2}{|c|}{$\begin{array}{l}\text { Anteriro crossbite } \\
\text { Prednji ukršten zagrižaj }\end{array}$}} & $\begin{array}{l}\text { No crossbite } \\
\text { Nema prednjeg ukrštenog zagrižaja }\end{array}$ & 0 & \multirow{5}{*}{6} \\
\hline & & $\begin{array}{l}\text { One or more teeth edge to edge } \\
\text { Kontakt sečivnih ivica jednog ili više sekutića }\end{array}$ & 1 & \\
\hline & & $\begin{array}{l}\text { One single tooth crossbite } \\
\text { Jedan sekutić u obrnutom preklopu }\end{array}$ & 2 & \\
\hline & & $\begin{array}{l}\text { Two teeth in crossbite } \\
\text { Dva sekutića u obrnutom preklopu }\end{array}$ & 3 & \\
\hline & & $\begin{array}{l}\text { More than two teeth in crossbite } \\
\text { Više od dva sekutića u obrnutom preklopu }\end{array}$ & 4 & \\
\hline \multirow{4}{*}{\multicolumn{2}{|c|}{$\begin{array}{l}\text { Overbite } \\
\text { Preklop sekutića }\end{array}$}} & $\begin{array}{l}\text { Less than } 1 / 3 \text { coverage of the lower incisor } \\
\text { Pokrivenost donjih sekutića manja od } 1 / 3\end{array}$ & 0 & \multirow{4}{*}{2} \\
\hline & & $\begin{array}{l}\text { Greater than } 1 / 3 \text { but less than } 2 / 3 \text { coverage } \\
\text { Pokrivenost donjih sekutića između } 1 / 3 \text { i } 2 / 3\end{array}$ & 1 & \\
\hline & & $\begin{array}{l}\text { Greater than } 2 / 3 \text { of the lower incisor } \\
\text { Pokrivenost donjih sekutića veća od } 2 / 3\end{array}$ & 2 & \\
\hline & & $\begin{array}{l}\text { Greater than or equal to full tooth coverage } \\
\text { Potpuna pokrivenost donjih sekutića }\end{array}$ & 3 & \\
\hline \multirow{5}{*}{\multicolumn{2}{|c|}{$\begin{array}{l}\text { Open bite } \\
\text { Otvoren zagrižaj }\end{array}$}} & $\begin{array}{l}\text { No open bite } \\
\text { Nema ga }\end{array}$ & 0 & \multirow{5}{*}{2} \\
\hline & & $\leq 1 \mathrm{~mm}$ & 1 & \\
\hline & & $1.1-2 \mathrm{~mm}$ & 2 & \\
\hline & & $2.1-4 \mathrm{~mm}$ & 3 & \\
\hline & & $>4 \mathrm{~mm}$ & 4 & \\
\hline \multirow{3}{*}{\multicolumn{2}{|c|}{$\begin{array}{l}\text { Centreline assessment } \\
\text { Odnos sredina zubnih nizova }\end{array}$}} & $\begin{array}{l}\text { Coincident } \\
\text { Sredine zubnih nizova se poklapaju }\end{array}$ & 0 & \multirow{3}{*}{4} \\
\hline & & $\begin{array}{l}1 / 4-1 / 2 \text { width of the lower incisor } \\
\text { Odstupaju između } 1 / 4 \text { i } 1 / 2 \text { širine donjeg sekutića }\end{array}$ & 1 & \\
\hline & & $\begin{array}{l}\text { Greater than } 1 / 2 \text { width of the lower incisor } \\
\text { Odstupaju više od } 1 \frac{1}{2} \text { širine donjeg sekutića }\end{array}$ & 2 & \\
\hline
\end{tabular}


Table 3. Scoring system for the Index of Complexity, Outcome and Need (ICON) [10]

Tabela 3. Sistem bodovanja za ICON [10]

\begin{tabular}{|c|c|c|c|}
\hline $\begin{array}{l}\text { Occlusal characteristics } \\
\text { Obeležja okluzije }\end{array}$ & $\begin{array}{l}\text { Severity } \\
\text { Mera izraženosti }\end{array}$ & $\begin{array}{l}\text { Scores } \\
\text { Bodovi }\end{array}$ & $\begin{array}{l}\text { Weighting } \\
\text { Koeficijenti }\end{array}$ \\
\hline $\begin{array}{l}\text { Dental aesthetics } \\
\text { Dentalna estetika }\end{array}$ & $\begin{array}{l}\text { Compared to one of } 10 \text { photographs of the Aesthetic Scale of IOTN } \\
\text { Upoređuje se s jednom od deset fotografija estetske skale IOTN }\end{array}$ & $1-10$ & 7 \\
\hline \multirow{6}{*}{$\begin{array}{l}\text { Upper arch crowding/spacing } \\
\text { Teskoba/rastresitost u gornjem zubnom nizu }\end{array}$} & $<2 \mathrm{~mm}$ & 0 & \multirow{6}{*}{5} \\
\hline & $2.1-5 \mathrm{~mm}$ & 1 & \\
\hline & $5.1-9 \mathrm{~mm}$ & 2 & \\
\hline & $9.1-13 \mathrm{~mm}$ & 3 & \\
\hline & $13.1-17 \mathrm{~mm}$ & 4 & \\
\hline & $>17 \mathrm{~mm}$ & 5 & \\
\hline \multirow{3}{*}{$\begin{array}{l}\text { Buccal occlusion in sagittal direction } \\
\text { Bočna okluzija u sagitalnom pravcu }\end{array}$} & $\begin{array}{l}\text { Good interdigitation } \\
\text { Pravilna interkuspidacija }\end{array}$ & 0 & \multirow{3}{*}{3} \\
\hline & $\begin{array}{l}\text { Any cusp relationship up to, but not including cusp to cusp } \\
\text { Između pravilne interkuspidacije i odnosa kvržica na kvržicu }\end{array}$ & 1 & \\
\hline & $\begin{array}{l}\text { Cusp to cusp relationship } \\
\text { Interkuspidacija u odnosu kvržica na kvržicu }\end{array}$ & 2 & \\
\hline \multirow{2}{*}{$\begin{array}{l}\text { Crossbite } \\
\text { Ukršten zagrižaj }\end{array}$} & $\begin{array}{l}\text { No crossbite } \\
\text { Nema ukrštenog zagrižaja }\end{array}$ & 0 & \multirow{2}{*}{5} \\
\hline & $\begin{array}{l}\text { Crossbite present } \\
\text { Prisutan ukršten zagrižaj }\end{array}$ & 1 & \\
\hline \multirow{4}{*}{$\begin{array}{l}\text { Overbite } \\
\text { Preklop sekutića }\end{array}$} & $\begin{array}{l}\text { Less than } 1 / 3 \text { lower incisor coverage } \\
\text { Pokrivenost donjih sekutića manja od } 1 / 3\end{array}$ & 0 & \multirow{4}{*}{4} \\
\hline & $\begin{array}{l}1 / 3 \text { to } 2 / 3 \text { coverage } \\
\text { Pokrivenost donjih sekutića između } 1 / 3 \mathrm{i}^{2 / 3}\end{array}$ & 1 & \\
\hline & $\begin{array}{l}2 / 3 \text { up to full coverage of lower incisor } \\
\text { Pokrivenost donjih sekutića veća od } 2 / 3\end{array}$ & 2 & \\
\hline & \begin{tabular}{|l} 
Full lower incisor coverage \\
Potpuna pokrivenost donjih sekutića
\end{tabular} & 3 & \\
\hline \multirow{5}{*}{$\begin{array}{l}\text { Open bite } \\
\text { Otvoren zagrižaj }\end{array}$} & $\begin{array}{l}\text { Edge to edge } \\
\text { Nema ga }\end{array}$ & 0 & \multirow{5}{*}{4} \\
\hline & $<1 \mathrm{~mm}$ & 1 & \\
\hline & $1.1-2 \mathrm{~mm}$ & 2 & \\
\hline & $2.1-4 \mathrm{~mm}$ & 3 & \\
\hline & $>4 \mathrm{~mm}$ & 4 & \\
\hline
\end{tabular}
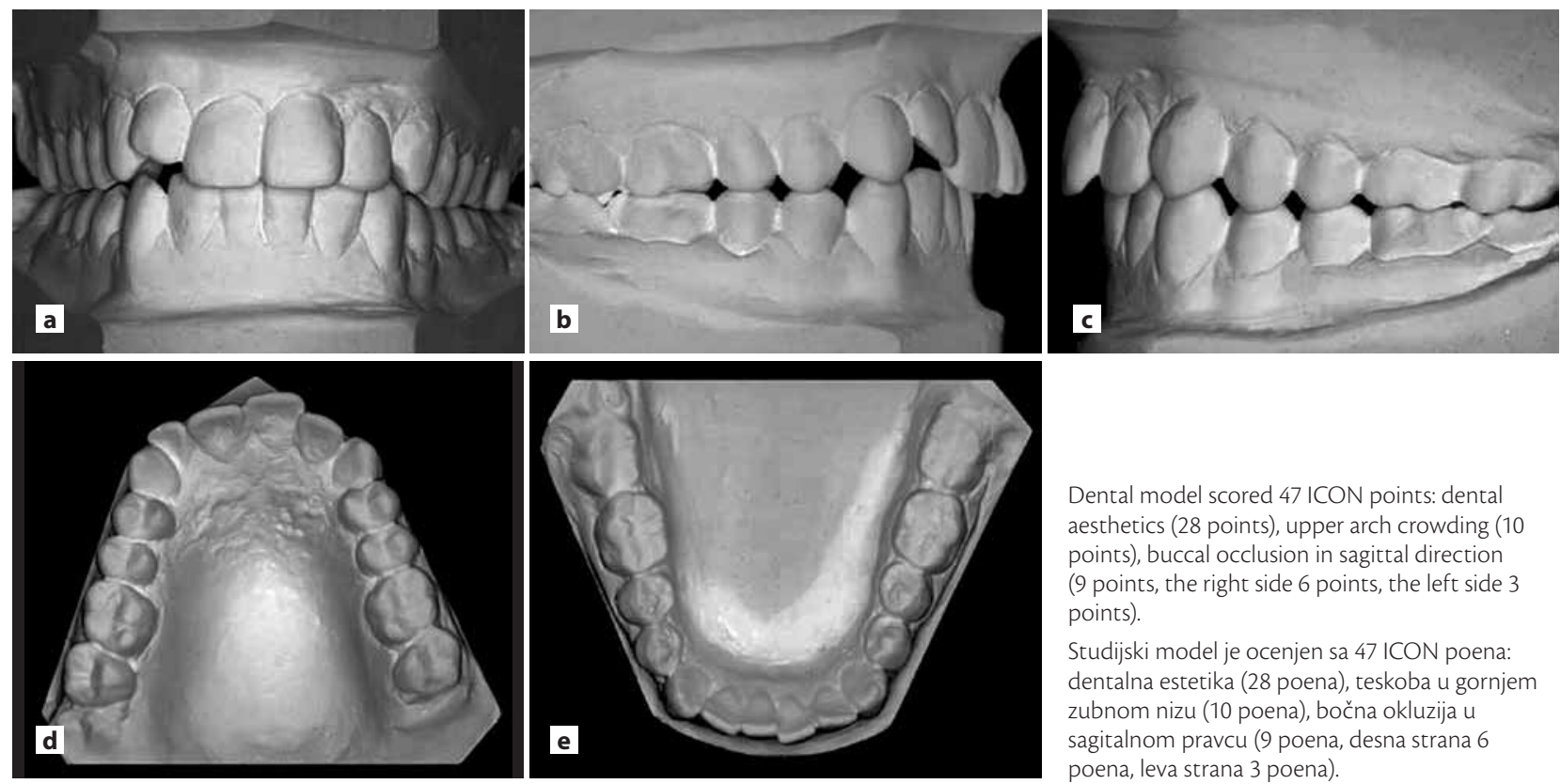

Dental model scored 47 ICON points: dental aesthetics (28 points), upper arch crowding (10 points), buccal occlusion in sagittal direction (9 points, the right side 6 points, the left side 3 points).

Studijski model je ocenjen sa 47 ICON poena: dentalna estetika (28 poena), teskoba u gornjem zubnom nizu (10 poena), bočna okluzija u sagitalnom pravcu ( 9 poena, desna strana 6 poena, leva strana 3 poena).

Figure 3a-e. Dental model assessed by the Index of Complexity, Outcome and Need (ICON) Slika 3a-e. Studijski model ocenjen sa ICON

overbite [9]. Scores are assigned to deviant occlusal traits and then multiplied by different coefficients and summed to produce an overall total. (Table 3, Figure 3). Score range for orthodontic treatment complexity, outcome and need has been suggested.

\section{RESULTS}

The results of this study showed that indices IOTN, PAR and ICON are reliable when applied to dental models. The results for IOTN are shown in Table 4. Weighted Kappa 
Table 4. Intraexaminer reliability for the Aesthetic and the Dental Health Component of IOTN

Tabela 4. Pouzdanost ispitivača za estetski i zdravstveni deo IOTN

\begin{tabular}{|c|c|c|c|}
\hline \multicolumn{2}{|l|}{$\begin{array}{l}\text { Parameter } \\
\text { Parametar }\end{array}$} & $\begin{array}{c}\text { Aesthetic } \\
\text { Component } \\
\text { Estetski deo }\end{array}$ & $\begin{array}{c}\text { Dental Health } \\
\text { Component } \\
\text { Zdravstveni deo }\end{array}$ \\
\hline \multicolumn{2}{|c|}{$\begin{array}{l}\text { Weighted Kappa } \\
\text { Koeficijent kapa }\end{array}$} & 0.72 & 0.79 \\
\hline \multirow{2}{*}{$95 \% \mathrm{Cl}$} & $\begin{array}{l}\text { Lower } \\
\text { Donji }\end{array}$ & 0.58 & 0.62 \\
\hline & $\begin{array}{l}\text { Upper } \\
\text { Gornji }\end{array}$ & 0.87 & 0.89 \\
\hline
\end{tabular}

$\mathrm{Cl}$ - confidence interval

$\mathrm{Cl}$ - interval poverenja

Tabela 5. Intraexaminer reliability for PAR and ICON

Tabela 5. Pouzdanost ispitivača za PAR i ICON

\begin{tabular}{|l|c|c|}
\hline $\begin{array}{l}\text { Parameter } \\
\text { Parametar }\end{array}$ & PAR & ICON \\
\hline $\begin{array}{l}\text { Mean difference in scores } \\
\text { Srednja vrednost razlika bodova }\end{array}$ & 0.5 & 0.8 \\
\hline $\begin{array}{l}\text { Root Mean Square Error } \\
\text { Koren srednje kvadratne greške }\end{array}$ & 2.1 & 4.5 \\
\hline p & $<0.01$ & $<0.01$ \\
\hline
\end{tabular}

coefficient for the Aesthetic Component of IOTN was 0.72 (0.58-0.87) and $0.79(0.62-0.89)$ for the Dental Health Component of IOTN. Intraexaminer reliability for PAR and ICON is shown in Table 5. The RMS Error was 2.1 for PAR scores and 4.5 for ICON scores. T test showed no statistically significant difference between PAR and ICON scores on two occasions $(\mathrm{p}<0.01)$.

\section{DISCUSSION}

An occlusal index has to fulfil the appropriate prerequisites before it can be applied in orthodontic practice: reliability, objectivity, simplicity, adaptability, sensitivity and specificity [11]. The reliability represents the extent to which it is possible to reproduce an assessment of an occlusal index in indentical conditions [12]. Intraexaminer and interexaminer reliability can be determined. There are three main components relevant for reliability assessment of an occlusal index: agreement, bias and validity [10]. The assessment of agreement is based on comparison of index scores of examiner(s) to "gold standard" which represents the opinion of orthodontic board consisting of leading experts. Bias exists when the overall scores of the examiner(s) are systematically higher or lower compared to the previous standard. Validity is expressed through variation of the examiner(s) scores and compared to acceptable criteria on clinical judgement.

\section{IOTN}

Over the years the advantages of IOTN were stated [10]. It is relatively quick and simple to use, systematic and informative. The special advantage is its ability to adjust to local environment. This is accomplished by modification of cut-off points to reach better agreement with local expert opinion or financial constraints. However, there are certain disadvantages, too [13]. Some authors believe that it may be too simplistic when determining orthodontic treatment need. According to the others, the association between deviant occlusal traits and dental health is weak. With orthodontic specialty improvements a need to monitor treatment standard emerged. This can not be accomplished using IOTN. Also, it is not possible to predict how complex the treatment would be. IOTN does not answer all the questions relevant to comprehensive orthodontic procedure, in which treatment need, assessment of complexity and outcome are present.

The values of weighted Kappa coefficient for IOTN ( 0.72 for the Aesthetic Component and 0.79 for the Dental Health Component) represent very high intraexaminer reliability. The Aesthetic Component has lower reliability compared to the Dental Health Component, but belongs to the same high category according to interpretation of Landis and Koch [14]. In reliability assessment, confidence interval, i.e. its range from lower to upper limit, is also important. The wider the interval, the lower the confidence. The reliability of the index is acceptable if the lower limit is greater than 0.60 [10]. In our study confidence interval was $0.58-0.87$ for the Aesthetic Component and 0.62-0.89 for the Dental Health Component. The lower limit for the Aesthetic Component of IOTN is approximate to minimal acceptable value.

In the study done by Fox et al. [15] on 55 dental models the values of weighted Kappa coefficients and corresponding confidence intervals were $0.88(0.82-0.93)$ for the Aesthetic Component and 0.82 (0.71-0.94) for the Dental Health Component.

Beglin et al. [16] reported in their study on 40 dental models that the values of weighted Kappa coefficients and corresponding confidence intervals were 0.93 (0.88-0.98) for the Dental Health Component and $0.93(0.89-0.97)$ for the Aesthetic Component. It was determined in the same study that the average value of weighted Kappa coefficients for the group of 15 examiners was 0.81 (0.81-0.82).

In previous studies the reliability of both components of IOTN was higher compared to the results of our study. Possible explanation for lower reliability of the Aesthetic Component might be the fact that it is not universally accepted in orthodontic profession and that there are disagreements on the sequence of ten photographs [17]. The second reason might be that the examiner was not trained in the use of IOTN, but followed procedure described in the literature. Variety and severity of malocclusions in the sample affect the results because it is known that higher variation in the sample influences better correlation of parameters that are analysed [14]. The sample in this study was two or three times smaller compared to the samples in previous studies. No matter there were differences with the literature data, the reliability of IOTN in this study was high enough to recommend it in practice.

\section{PAR}

PAR measures orthodontic treatment outcome comparing the severity of malocclusion prior to treatment and at the end of treatment. The index was originally adjusted 
to reflect British orthodontic standard. After validation assessment in the USA the weightings were modified and the assessment of crowding in the lower frontal segment omitted, to reach better agreement with american experts [18]. PAR is used all around the world for determining the success of different treatment methods [19]. There are certain disadvantages of this index described in the literature [20, 21]. In assessment of treatment outcome PAR does not take into account: periodontal tissue damage, enamel decalcification, root resorption, occlusal functionality and facial aesthetics. Additionaly, it may not be sufficiently critical of residual extraction sites, unacceptable incisor inclination and rotations of teeth. Conversely, it may exhibit high criticism in assessment of cases with limited treatment options. It is stated that PAR informs only about one aspect of orthodontic treatment and has no clear cut-off point for treatment outcome acceptability. Depending on a geographical region different weightings have been used. It is necessary to check its validity every five years in compliance with an increasing knowledge of influence of malocclusion on oral health.

The assessment of reliability and validity of PAR recorded on dental models was made in the study which presented this index to public [8]. For that purpose intraclass correlation coefficient showed excellent intraexaminer and interexaminer reliability. It is not possible to compare these results to our results directly, because the different statistical method was used to examine the reliability of the index.

According to the literature, the reliability of PAR is clinically acceptable if the root mean square error is lower than 5 PAR points [10]. This requirement was fulfilled in this study (2.1 PAR points). Our results are in accordance with the results of afore mentioned study conducted by Fox et al. [15], in which the root mean square error was 2.33 PAR points. T-test confirmed that there was no statistically significant difference between the scores of two consecutive measurements. It implies that it is reliable to use PAR on dental models.

\section{ICON}

ICON is derived from expert opinions of 97 orthodontists from Great Britain, Greece, Italy, Hungary, Germany, Norway, the USA, the Netherlands and Spain [22, 23]. The international panel of orthodontists gave subjective judgements on 240 initial dental models and 98 pairs of dental models of treated patients. Five occlusal components were found to be highly predictive of mean orthodontist opinion for malocclusion severity, treatment need, complexity and outcome. ICON is the first index to provide information on different aspects of orthodontic treatment and also the first index based on the international criteria. It proved to be simple to use because it records a small number or deviant occlusal traits and does not demand memorising their sequence by severity. It is hard to assess dental aesthetics in transitory stages of early mixed dentition, therefore it is recommened to use ICON in late mixed and permanent dentition [15].
The reliability of ICON is clinically acceptable if the root mean square error is less than 9 ICON points[10]. In this study, the root mean square error was 4.5 ICON points. T test showed there was no statistically significant difference between scores in two consecutive measurements. The reliability was higher compared to the results of study conducted by Fox et al. [15], in which the root mean square error was 7.9 ICON points.

\section{CONCLUSION}

The application of occlusal indices in everyday practice provides easier identification of potential orthodontic patients and their appropriate referal to orthodontic examination and treatment, as well as monitoring and promotion of standards of orthodontic treatment. Occlusal indices are reliable diagnostic methods.

\section{REFERENCES}

1. Linklater RA, Fox NA. The long-term benefits of orthodontic treatment. Br Dent J. 2002; 192:583-7.

2. McGuiness NJ, Stephens CD. An introduction to indices of malocclusion. Dent Update. 1994; 21:140-4.

3. Shaw WC, Richmond S, O'Brien KD. The use of occlusal indices: A European perspective. Am J Orthod Dentofac Orthop. 1995; 107:1-10.

4. Ovsenik, M. Assessment of malosslusion in the permanent dentition: reliability of intraoral measurements. Eur J Orthod. 2007; 29(6):654-9.

5. Evans R, Shaw WC. A preliminary evaluation of an illustrated scale for rating dental attractiveness. Eur J Orthod. 1987; 9:314-8.

6. Brook FH, Shaw WC. The development of an index of orthodontic treatment priority. Eur J Orthod. 1989; 11:309-20.

7. Souames M, Bassigny F, Zenati N, Riordan PJ, Boy-Lefevre ML. Orthodontic treatment need in French schoolchildren: an epidemiological study using the Index of Orthodontic Treatment Need. Eur J Orthod. 2006; 28:605-9.

8. Richmond S, Shaw WC, O'Brien KD, Buchanan IB, Jones R, Stephens CD, et al. The development of the PAR Index (Peer Assessment Rating): reliability and validity. Eur J Orthod. 1992; 14:125-39.

9. Daniels C, Richmond S. The development of the index of complexity, outcome and need (ICON). J Orthod. 2000; 27:149-62.

10. Richmond S. Evaluating Effective Orthodontic Care. Cardiff: First Numerics Ltd.; 2005.

11. DeGuzman L, Bahiraei D, Vig KWL, Vig PS, Ewyant RJ, O'Brien K. The validation of the Peer Assessment Rating Index for malocclusion severity and treatment difficulty. Am J Orthod Dentofac Orthop. 1995; 107:172-6.

12. Roberts CT, Richmond S. The design and analysis of reliability studies for the use of epidemiological and audit indices in orthodontics. Br J Orthod. 1997; 24:139-47.

13. Cooper S, Mandall NA, Dibiase D, Shaw WC. The reliability of the Index of Orthodontic Treatment Need over time. J Orthod. 2000; 27:47-53.

14. Landis JR, Koch GG. The measurement of observer agreement for categorical data. Biometrics. 1977; 33:159-74.

15. Fox NA, Daniels C, Gilgrass T. A comparison of the index of complexity, outcome and need (ICON) with the peer assessment rating (PAR) and the index of orthodontic treatment need (IOTN). Br Dent J. 2002; 193:225-30.

16. Beglin FM, Firestone AR, Vig KWL, Beck FM, Kuthy RA, Wade D. A comparison of the reliability and validity of 3 occlusal indexes of orthodontic treatment need. Am J Orthod Dentofac Orthop. 2001; 120:240-6

17. Johansson AM, Follin ME. Evaluation of the aesthetic component of the Index of Orthodontic Treatment Need by Swedish orthodontists. Eur J Orthod. 2005; 27:160-6. 
18. DeGuzman L, Bahiraei D, Vig KWL, Vig PS, Ewyant RJ, O'Brien K. The validation of the Peer Assessment Rating Index for malocclusion severity and treatment difficulty. Am J Orthod Dentofac Orthop. 1995; 107:172-6.

19. Richmond S, Shaw WC. The PAR Index (Peer Assessment Rating): methods to determine outcome of orthodontic treatment in terms of improvement and standards. Eur J Orthod. 1992; 14:180-7.

20. Firestone AR, Beck FM, Beglin FM, Vig KWL. Evaluation of the peer assessment rating (PAR) index as an index of orthodontic treatment need. Am J Orthod Dentofac Orthop. 2002; 122:463-9.

21. Dyken RA, Sadowsky PL, Hurst D. Orthodontic outcomes assessment using the peer assessment rating index. Angle Orthod. 2001; 71:164-9.

22. Richmond S, Daniels CP. International comparisons of professional assessments in orthodontics: Part 1- Treatment need. Am J Orthod Dentofac Orthop. 1998; 113:180-5.
23. Richmond S, Daniels CP. International comparisons of professional assessments in orthodontics: Part 2 - Treatment outcome. Am J Orthod Dentofac Orthop. 1998; 113:324-8.

\author{
Address for correspondence \\ Jelena Đorđević \\ Department of Orthodontics \\ School of Dentistry \\ Gastona Gravijea 2, 11000 Belgrade \\ Serbia \\ Email: drjelena@pochta.ru
}




\title{
Primena okluzivnih indeksa u ortodontskoj praksi
}

\author{
Jelena Đorđević, Ivana Šćepan, Branislav Glišić \\ Klinika za ortopediju vilica, Stomatološki fakultet, Univerzitet u Beogradu, Beograd, Srbija
}

\begin{abstract}
KRATAK SADRŽAJ
Uvod Okluzivni indeksi su uvedeni u praksu sa ciljem da se poboljšaju dijagnostički kriterijumi i omogući objektivna procena težine malokluzije. Cilj ovog rada je bio da se predstave najčešće korišćeni okluzivni indeksi u ortodontskoj praksi i utvrdi pouzdanost njihove primene na studijskim modelima.

Materijal i metode rada Za analizu su odabrana tri okluzivna indeksa: Index of Orthodontic Treatment Need (IOTN), Peer Assessment Rating (PAR) i Index of Complexity, Outcome and Need (ICON). U istraživanju je korišćeno 20 studijskih modela pacijenata Klinike za ortopediju vilica Stomatološkog fakulteta u Beogradu s malokluzijama različitog tipa i težine u stalnoj denticiji. Svi modeli su ocenjeni sa tri pomenuta indeksa dva puta u razmaku od dva meseca radi utvrđivanja pouzdanosti.

Rezultati Rezultati analize su pokazali da je pouzdanost sva tri indeksa bila dobra. Za IOTN pouzdanost je izražena koeficijentom kapa $(0,72$ za estetski i 0,79 zdravstveni deo indeksa), dok je za PAR i ICON izračunat koren srednje kvadratne greške $(2,1$ i 4,5). Nije bilo statistički značajne razlike u broju bodova između dva merenja ova dva indeksa $(p<0,01)$.

Zaključak Primena okluzivnih indeksa omogućava ortodontima određivanje prioriteta u zbrinjavanju pacijenata, planiranje ortodontske službe, pridržavanje i promociju standarda. Okluzivni indeksi su pouzdani dijagnostički kriterijumi koji mogu značajno uticati na plan lečenja malokluzija.
\end{abstract}

Ključne reči: malokluzija; okluzivni indeksi; ortodoncija; studijski modeli

\section{UVOD}

Dugo se već zna da ortodontsko lečenje poboljšava zdravlje denticije, oralne funkcije, izgled lica i kvalitet života pacijenta. S druge strane, poslednjih godina se sve veća pažnja posvećuje potencijalnim rizicima ortodontskog lečenja: resorpciji korena, demineralizaciji gleđi zuba, zapaljenju desni, gubitku periodontalnog pripoja, zapaljenju pulpe, alergijskoj reakciji, traumi, jatrogenom oštećenju, neuspešnom lečenju i recidivu [1]. Pre donošenja odluke o ortodontskom lečenju trebalo bi ozbiljno razmotriti prednosti i rizike ovakvog načina lečenja. Stoga je neophodna precizna dijagnostika, pa su zato u poslednje četiri decenije predloženi brojni okluzivni indeksi radi poboljšanja dijagnostičkih kriterijuma [2].

Okluzivni indeksi se mogu svrstati u pet kategorija: dijagnostički, epidemiološki, indeksi potrebe za ortodontskim lečenjem, indeksi rezultata ortodontskog lečenja i indeksi složenosti ortodontskog lečenja [3]. Metode kojima se opisuje, procenjuje i klasifikuje okluzija se mogu podeliti na kvalitativne i kvantitativne. Razlikuju se ne samo po morfološkim ili funkcionalnim kriterijumima, već i po načinu određivanja: na studijskim modelima, klinički ili na oba načina [4]. Pregledom literature se uočava da su u praksi najčešće korišćena tri okluzivna indeksa (IOTN, PAR, ICON).

Index of Orthodontic Treatment Need (IOTN), čiji je prvobitan naziv bio Index of Orthodontic Treatment Priority, predložili su Evans (Evans) i Šo (Shaw) [5, 6] 1987. godine. IOTN se koristi u epidemiološke svrhe i za utvrđivanje individualne potrebe za ortodontskim lečenjem [7]. Peer Assessment Rating (PAR) pripada grupi okluzivnih indeksa koji mere uspešnost ortodontskog lečenja. Za njegovo uvođenje u praksu 1992. godine zaslužna je radna grupa za britanske ortodontske standarde [8]. Index of Complexity, Outcome and Need (ICON) je nastao kao izraz potrebe da se u jednom indeksu objedine procena potrebe za lečenjem, složenost i rezultati lečenja. Ovaj in- deks su predložili Danijels (Daniels) i Ričmond (Richmond) [9] 2000. godine na osnovu rezultata opsežne međunarodne studije.

Cilj ovog rada je bio da se predstave najčešće korišćeni okluzivni indeksi u ortodontskoj praksi i utvrdi pouzdanost njihove primene na studijskim modelima.

\section{MATERIJAL I METODE RADA}

U ovom istraživanju je korišćeno dvadeset studijskih modela pacijenata Klinike za ortopediju vilica Stomatološkog fakulteta u Beogradu. Odabrane su malokluzije različitog tipa i težine u stalnoj denticiji. Iz uzorka su isključeni studijski modeli pacijenata s kraniofacijalnim deformitetima i rascepima. Svi modeli su označeni brojevima i ocenjeni sa tri okluzivna indeksa (IOTN, PAR i ICON) dva puta u razmaku od dva meseca. Raspoređeni su na osnovu tablice slučajnih brojeva da bi se izbegla subjektivnost pri ocenjivanju. Sve vrednosti indeksa su upisane u posebno pripremljen istraživački upitnik. Ocenjivanje modela je obavio jedan ispitivač.

Statistička analiza podataka je urađena u programu Statistical Package for Social Sciences (SPSS), verzija 11.5 (Chicago, Illinois). Koeficijentom kapa sa 95-procentnim intervalom poverenja $(95 \% \mathrm{CI})$ određena je pouzdanost estetskog i zdravstvenog dela IOTN s obzirom na to da su podaci za ovaj indeks kategoričkog tipa. Koeficijent kapa predstavlja modifikaciju prostog koeficijenta kapa. Svako odstupanje dva merenja nosi određeni težinski faktor [10]. Vrednost ovog koeficijenta je u opsegu od 0 (nema saglasnosti među merenjima osim slučajne) do 1 (savršena saglasnost). Pouzdanost PAR i ICON, čiji su podaci kontinuiranog tipa, izražena je korenom srednje kvadratne greške. Time su obuhvaćene slučajna greška (greška merenja) i subjektivnost pri ocenjivanju (ukoliko postoji). Statistička značajnost razlika ocena u dva merenja je ispitana t-testom za PAR i ICON sa nivoom značajnosti od 0,01 . 


\section{IOTN}

IOTN se sastoji od dva nezavisna dela: estetskog i zdravstvenog $[5,6]$. Estetsku skalu indeksa čini 10 frontalnih fotografija stalne denticije. Zdravstveni deo indeksa okluzivne anomalije svrstava u pet kategorija prema uticaju koji imaju na oralno zdravlje. Najveća pažnja se pridaje nedostatku zuba, incizalnom stepeniku, ukrštenom zagrižaju, vertikalnom preklopu sekutića i teskobi. Ocena se daje na osnovu najtežeg kliničkog nalaza (Tabela 1, Slika 1).

\section{PAR}

Ovim indeksom se ocenjuju teskoba, rastresitost i impaktirani zubi u prednjim segmentima zubnih nizova, bočna okluzija u sagitalnoj, vertikalnoj i transverzalnoj ravni, incizalni stepenik, prednji ukršten zagrižaj, dubok (otvoren) zagrižaj, vertikalni preklop sekutića i odnos sredina zubnih nizova [8]. Okluzivnim anomalijama se dodeljuju bodovi, koji se množe odgovarajućim koeficijentima a zatim sabiraju (Tabela 2, Slika 2). Na osnovu razlike između broja bodova pre i posle lečenja ocenjuje se uspešnost lečenja. Ako je nakon završetka lečenja broj bodova smanjen za $70 \%$ i više u odnosu na broj bodova pre lečenja, ono se smatra uspešnim.

\section{ICON}

Ovim indeksom se ocenjuju dentalna estetika, teskoba (rastresitost) u gornjem zubnom nizu, bočna okluzija u sagitalnom pravcu, ukršten zagrižaj i vertikalni preklop sekutića [9]. Okluzivnim anomalijama se dodeljuju bodovi, a zatim množe odgovarajućim koeficijentima i sabiraju radi dobijanja konačne ocene (Tabela 3, Slika 3). U literaturi je predložena skala na osnovu koje se određuju potreba za lečenjem, složenost i uspešnost lečenja.

\section{REZULTATI}

Rezultati analize su pokazali da je primena IOTN, PAR i ICON na studijskim modelima pouzdana. Rezultati za IOTN su prikazani u tabeli 4 . Za estetski deo indeksa koeficijent kapa je bio 0,72 (0,58-0,87), a za zdravstveni deo 0,79 (0,62-0,89). U tabeli 5 je prikazana pouzdanost ocena ispitivača za PAR i ICON. Slučajna greška je bila 2,1 bod za PAR i 4,5 bodova za ICON. Rezultati t-testa su pokazali da nema statistički značajne razlike u broju PAR i ICON bodova u dva merenja $(\mathrm{p}<0,01)$.

\section{DISKUSIJA}

Okluzivni indeks treba da ispuni sledeće kriterijume pre nego što se primeni u ortodontskoj praksi: pouzdanost, objektivnost, jednostavnost, prilagodljivost, senzitivnost i specifičnost [11]. Pouzdanost predstavlja meru u kojoj je moguće ponoviti određivanje okluzivnog indeksa pod istovetnim uslovima, a može se odrediti u odnosu na istog ispitivača ili između grupe ispitivača [12]. Za procenu pouzdanosti okluzivnog indeksa neophodne su saglasnost, subjektivnost i verodostojnost ocenjivanja
[10]. Procena saglasnosti se vrši upoređivanjem vrednosti indeksa jednog ili više ispitivača sa tzv. zlatnim standardom, koji predstavlja mišljenje ortodontske komisije sačinjene od vodećih stručnjaka. Subjektivnost, odnosno pristrasnost postoji kada dati ispitivač sistematski daje više ili niže ocene u odnosu na pomenuti standard. Verodostojnost ocenjivanja se izražava kroz njegove varijacije i prihvatljivost u odnosu na kliničko odlučivanje.

\section{IOTN}

Dugogodišnjom primenom IOTN uočene su njegove značajne prednosti [10]. Ovaj indeks se relativno brzo i jednostavno određuje, sistematičan je i informativan. Posebna prednost je to što se može prilagoditi lokalnim uslovima, što se postiže podešavanjem graničnih vrednosti indeksa u skladu sa stavovima stručnjaka date regije ili finansijskim ograničenjima. Međutim, uočeni su i nedostaci [13]. Neki autori smatraju da korišćenje ovoga indeksa isuviše pojednostavljuje pitanje potrebe za ortodontskim lečenjem. Navodi se slaba korelacija između devijantnih odlika okluzije i dentalnog zdravlja. S unapređenjem ortodontske struke pojavila se i potreba za pridržavanjem standarda lečenja. To ovim indeksom nije moguće postići. Takođe, nije moguće ni predvideti koliko će lečenje biti složeno. IOTN ne daje odgovore na sva pitanja koja se tiču savremenog postupka ortodontskog lečenja, u kojem su potreba za lečenjem, procena složenosti i uspešnosti lečenja neraskidivi delovi jedne celine.

Vrednosti koeficijenta kapa za IOTN (0,72 za estetski i 0,79 za zdravstveni deo) označavaju veoma visoku pouzdanost merenja ispitivača. Estetski deo IOTN ima nižu pouzdanost od zdravstvenog dela, ali prema tumačenju koje su dali Landis (Landis) i Koh (Koch) [14], pripada istoj visokoj kategoriji pouzdanosti. U proceni pouzdanosti, osim vrednosti koeficijenta kapa, značajna je širina intervala poverenja, odnosno opseg od donje do gornje granice. Što je opseg veći, pouzdanost je manja. U literaturi se navodi da je pouzdanost ocenjivanja jednim indeksom prihvatljiva ukoliko donja granica poverenja nije manja od 0,6 [10]. U ovom radu širina intervala poverenja je bila 0,58-0,87 za estetski deo i 0,62-0,89 za zdravstveni deo indeksa. Donja granica intervala poverenja za estetski deo indeksa je bila približna najmanjoj prihvatljivoj vrednosti.

U istraživanju Foksa (Fox) i saradnika [15] na 55 studijskih modela vrednosti koeficijenata kapa i odgovarajućih intervala poverenja bile su $0,88(0,82-0,93)$ za estetski deo i $0,82(0,71$ $0,94)$ za zdravstveni deo indeksa. Rezultati istraživanja Beglina (Beglin) i saradnika [16] na 40 studijskih modela su pokazali vrednost koeficijenata kapa i odgovarajućih intervala poverenja od 0,93 $(0,88-0,98)$ za zdravstveni deo i $0,93(0,89-0,97)$ za estetski deo indeksa. U istom radu je utvrđena prosečna vrednost koeficijenta kapa za grupu od 15 ispitivača, koja je iznosila $0,81(0,81-0,82)$. Pouzdanost određivanja oba dela IOTN u navedenim istraživanjima je bila veća nego u ovom istraživanju. Objašnjenje za malu pouzdanost estetskog dela IOTN je u tome što on nije opšteprihvaćen i što postoje neslaganja u vezi s redosledom predloženih deset fotografija [17]. Drugi razlog je to što ispitivač nije prošao zvaničnu obuku za indeks, već se koristi postupak određivanja indeksa opisan u literaturi. Raznovrsnost i težina malokluzija u uzorku utiču na dobijene rezultate 
tako što veće varijacije u uzorku dovode do bolje korelacije ispitivanih parametara [14]. Uzorak u ovom istraživanju je dva ili tri puta manji od uzoraka u pomenutim studijama. Bez obzira na razlike u podacima u literaturi, pouzdanost IOTN u ovom istraživanju je bila dovoljno visoka.

\section{PAR}

PAR uspešnost ortodontskog lečenja određuje poređenjem težine malokluzije na početku i na kraju lečenja. Indeks je prvobitno bio prilagođen britanskom ortodontskom standardu. Nakon provere validnosti indeksa u Sjedinjenim Američkim Državama, neki koeficijenti su izmenjeni i usaglašeni, pa je i merenje teskobe u prednjem segmentu donjeg zubnog niza izostavljeno [18]. PAR se primenjuje širom sveta za utvrđivanje uspešnosti različitih metoda lečenja [19]. U literaturi se, međutim, navode pojedini nedostaci ovoga indeksa [20,21]. Pri proceni rezultata lečenja on ne uzima u obzir oštećenje parodontalnog tkiva, demineralizaciju gleđi zuba, resorpciju korena, funkcionalnost okluzije i izgled lica. Pored toga, nedovoljno je kritičan prema rezidualnim ekstrakcionim prostorima, nepovoljnim inklinacijama sekutića i rotacijama zuba. Takođe, smatra se da je prestrog u oceni slučajeva s ograničenim mogućnostima lečenja, da pruža informaciju samo o jednom aspektu ortodontskog lečenja i da nema jasno utvrđenu graničnu vrednost za prihvatanje rezultata lečenja. U zavisnosti od geografske regije koriste se i različiti koeficijenti. Neophodno je proveravati validnost indeksa svakih pet godina u skladu s nivoom znanja o uticaju malokluzija na oralno zdravlje.

Procena pouzdanosti i validnosti PAR u oceni studijskih modela data je u radu koji je predstavio ovaj indeks stručnoj javnosti [8]. U tu svrhu je korišćen unutarklasni koeficijent korelacije, koji je pokazao odličnu pouzdanost indeksa. Rezultate ove studije nije moguće direktno uporediti s rezultatima našeg istraživanja, jer je korišćena drugačija statistička metoda za ispitivanje pouzdanosti indeksa.

Prema navodima iz literature, pouzdanost PAR je klinički prihvatljiva ukoliko je koren srednje kvadratne greške manji od pet bodova [10]. U ovom istraživanju je taj uslov zadovoljen $(2,1$ bod). Dobijeni rezultati su u saglasnosti s rezultatima istraživanja Foksa i saradnika [15], u kojem je koren srednje kvadratne greške za PAR bio 2,33 boda. Nalazi t-testa su potvrdili da nema statistički značajne razlike u broju bodova dva uzastopna merenja. To pokazuje da je PAR pouzdan za primenu na studijskim modelima.

\section{ICON}

ICON je izveden iz mišljenja 97 stručnjaka za ortodonciju iz Velike Britanije, Grčke, Italije, Mađarske, Nemačke, Norveške, SAD, Holandije i Španije [22, 23] . Međunarodni skup ortodonata je ocenio 240 studijskih modela pacijenata pre početka lečenja i 98 parova studijskih modela lečenih pacijenata. Utvrđeno je da se na osnovu pet činilaca okluzije može s velikom verovatnoćom predvideti prosečno mišljenje ortodonata o težini malokluzije, potrebi za lečenjem, složenosti i uspešnosti lečenja. ICON je prvi indeks koji objedinjuje različite aspekte ortodontskog lečenja i koji je zasnovan na međunarodnim kriterijumima. Pokazalo se da je jednostavan za korišćenje jer ocenjuje mali broj okluzivnih obeležja i ne zahteva pamćenje redosleda devijantnih okluzivnih odlika prema težini. U prelaznim stadijumima s ranom mešovitom denticijom teško je procenjivati estetiku, pa se zato ICON preporučuje u kasnoj mešovitoj, odnosno stalnoj denticiji [15].

Pouzdanost ovog indeksa je klinički prihvatlijiva ukoliko je koren srednje kvadratne greške manji od devet bodova [10]. U ovom istraživanju je koren srednje kvadratne greške bio 4,5 bodova. Rezultati t-testa su pokazali da nema statistički značajne razlike u broju bodova dva uzastopna merenja. Pouzdanost je bila veća nego u studiji Foksa i saradnika [15], u kojoj je koren srednje kvadratne greške bio 7,9 bodova.

\section{ZAKLJUČAK}

Primena okluzivnih indeksa u svakodnevnoj praksi omogućava lakše prepoznavanje potencijalnih ortodontskih pacijenata i njihovo pravovremeno upućivanje na ortodontski pregled i lečenje, kao i pridržavanje i promovisanje standarda ortodontskog lečenja. Okluzivni indeksi u kliničkoj praksi su vrlo pouzdane dijagnostičke metode koje mogu značajno uticati na plan lečenja brojnih malokluzija. 